\title{
Biological Aspects of Scheloribates laevigatus (Acari: Oribatida) when Fed on Mixture of the Free-Living Nematod, Eudiplogaster phlagellicaudatus and Potato in the Laboratory
}

\author{
M. M. E. EImoghazy ${ }^{\star}$, H. M. G. El-Kawas ${ }^{\star *}$ and M. S. Salman ${ }^{\star \star}$ \\ "Agric. Znology and Nematology Dept., Fac. of Agric., Al-Azhar Univ., Cairo, Egypt. \\ "*Plant Protection Research Institute, Agriculture Research Center, Dokki, Giza, Egypt.
}

\begin{abstract}
Scheloribates laevigatus (Koch) was able to develop and reproduce when fed on mixture of free-living nematod, Eudiplogaster phlagellicaudatus (Andrassy) and potato. Temperature had a significant effect on duration of the life cycle and all life span of this species. As temperature changed between 25 and $30^{\circ} \mathrm{C}$, the incubation period decreased. Both male and female immature stages decreased when temperature increased between 25 and $30^{\circ} \mathrm{C}$. Life cycle of male reached adulthood in a shorter period than that of female. This period decreased from $24.67 \pm 0.26$ to $21.25 \pm 0.53$ days for male and from $28.01 \pm 0.66$ to $23.16 \pm 0.98$ days for female at 25 and $30^{\circ} \mathrm{C}$, respectively. Temperature also negatively affected the adult female longevity and fecundity. It was found that the greatest average number of eggs deposited by female was $36.88 \pm 2.13$ at $25^{\circ} \mathrm{C}$; this decreased to $29.63 \pm 2.55$ at $30^{\circ} \mathrm{C}$.
\end{abstract}

Key Words: Oribatida, Scheloribates laevigatus, Biological aspects, Eudiplogaster phlagellicaudatus, Temperaiure.

\section{INTRODUCTION}

The oribatid mites are of economic importance owing to the discovery that many of them have been found to be hosts of various tape-worms. They are also important factors in promoting soil fertility through breaking down organic matter by digestion (Darwish, 1977). Oribatids are among the most abundant soil arthropods. They are considered to be important agents in regulating microbial activity in litter decomposition which is related to their feeding habits (Seastedt, 1984: Zinkler et al., 1986; Moore and Walter, 1988; Siepel \& Maaskamp, 1994; Khalil, 2005). Different species show different arrays of digestive enzymes (Siepel, 1990), and different preferences for specific food items correlated with cheliceral size and shape (Kaneko, 1988). The trophic niche differentiation of oribatid mites is much greater than expected before, and this contributes to their high biodiversity (Schneider et al., 2004; Erdmann et al., 2007). Oribatid mites are primarily particulate feeding saprophagous and mycophagous mites, feeding on living and dead organic material, such as moss and fungi (Johnston \& Crossley, 1993 and Walter \& Proctor, 1999). Few species are opportunistic predators, but none are parasitic (Behan-Pelletier, 1999). The diet of most oribatids may vary depending on habitat characteristics, season and/or microbe availability, which may be an adaptation to a variable environment (Wolf and Rockett, 1984 and Norton, 1985). There are no species currently known to specialize on a single fungal species (Schneider and Maraun, 2005). Oribatids may feed on the dead parenchymal tissue of leaves (phyllophagy) or the woody structural tissue of dead plants (xylophagy), microbivores feed on fungal hyphae or spores (mycophages), on bacteria (bacteriophages) or lichens and algae (phycophages), and some species are completely non-specialized (panphytophages) (Luxton, 1972; Schneider et al., 2004).

Scheloribates laevigatus (Koch) is a panphytophagous oribatid feeding on all kinds of plant or fungal tissues (Luxton, 1972). This species showed lower preference for grass litter (Holcus lanatus) than for the green bark algae Protococcus spp. (Desmococcus vulgaris) (Hubert et al., 1999). This species was classified as fungivorous grazer feeding on fungi, which indicates indirect feeding on litter (Siepel \& Ruiter-Dijkman, 1993 and Khalil et al., 2011). In 1999 Khalil et al. argued that food availability supports fecundity in this species because the animal could feed on a large number of different food items. The objective of this study was to investigate the biology of oribatid mite, $S$. laevigatus on tested food at two temperatures.

\section{MATERIALS AND METHODS}

\section{Pure culture:}

For preparing pure culture of the tested mites, plastic cups of $(1.5 \mathrm{~cm}$ high $\times 2.5 \mathrm{~cm}$ in diameter $)$ were filled up to $0.5 \mathrm{~cm}$ with plaster of Paris and activated charcoal in the rate of 8: 2 respectively. One adult female and male of the species were placed in the prepared cup, supplied with food and drops of water added daily to maintain suitable relative humidity and kept in an incubator at $25 \pm 1^{\circ} \mathrm{C}$.

For individual rearing, sixty newly deposited eggs were transferred from the mother culture singly one to every rearing plastic cell of $(1.5 \mathrm{~cm}$ high $\mathrm{x}$ $2.5 \mathrm{~cm}$ in diameter) at 25 and $30 \pm 1^{\circ} \mathrm{C}$. Each newly hatched larva was supplied with food kept till 
reaching maturity. Mites were examined twice daily. Observations concerning all biological aspects were recorded allover the mite life.

\section{Source of food:}

Free-living nematods, E. phlagellicaudatus were added to a Petri-dish containing slices of potatoes and few drops of water as a food source of rearing nematodes. Petri-dish was left for $5-7$ days at $25 \pm$ $1^{\circ} \mathrm{C}$. By using a fine brush, one or two drops of this feeding mixture were used as a source of food for $S$. laevigatus.

\section{Statistical analysis:}

The numerical data collected were computerized by using SPSS program (Statistical Package of Social Science) program, version 16.0.0, 2007. Significant differences of $S$. lacvigatus by temperantre were performed by IndependentSamples l' test $(\mathrm{p}<0.05)$.

\section{RESULTS AND DISCUSSION}

\section{Biological Aspects:}

\section{Hatching:}

Eggs of this species are smooth, whitish, then become creamy before hatching. Hatching occurs through a longitudinal median slit.

\section{Moulting:}

Immature stages of this species when full grown enter a quiescent period during which individual stop feeding. Any active immature stage of oribatid feeds until the cuticle is quite distended. Immatures of $S$. laevigatus seek dry, protected spots in the biological cell. After the immature stage finds a suitable place, it becomes quiescent and don't move even if violently disturbed. The duration of quiescent stage varies according to stage and temperature. At the end of the premoulting period the old cuticle splits on the notogasteral membrane from posterior most regions to the level of the fourth leg. The next stage expands and protrules from the split, and then remains that way until the legs and mouth parts have hardened. This is called the hardening period. This period took more than two hours.

These results agree with Narsapur (1983) who stated that, during the moult, the cuticle of the preceding stage split along the posterior border, the split occurring from the posterior most point of hysterosoma up to the level of the $4^{\text {th }}$ leg on either side.

Most of the pressure to split the old cuticle is supplied by the expanding body. The expansion is rapid, and the subsequent stage hardened in an expanded state. The legs aren't used until hardened, and then used to withdraw the individual fom the old cuticle.

\section{Development and Reproduction:}

Both male and female of this species pass through four active developmental stages before reaching adult (one larval and three nymphal stages; each active stage is followed by quiescent one).

The life cycle of $S$. laevigatus was studied in the laboratory on the feeding mixture of the free-living nematod, E. phlagellicaudatus and potato at 25 and $30 \pm 1{ }^{\circ} \mathrm{C}$. Results revealed that temperature had a significant effect on the duration of life cycle and life span. As temperature changed from 25 to $30^{\circ} \mathrm{C}$, the incubation period decreased from $2.58 \pm 0.20$ to $2.33 \pm 0.41$ days for male and from $2.81 \pm 0.40$ to $2.66 \pm 0.40$ for female (Table 1).

It was also found that the duration of both male and female immature stages decreased when temperature increased from 25 to $30^{\circ} \mathrm{C}$. As the duration of male immature stages decreased from $12.08 \pm 0.58$ to $10.01 \pm 0.55$ days for active and $9.92 \pm 0.66$ to $8.75 \pm 0.42$ days for quiescent stages, relative values of fernale decreased from $13.78 \pm 0.58$ to $10.69 \pm 0.60$ days for active and $11.47 \pm 0.43$ to $9.97 \pm 0.74$ days for quiescent stages, respectively.

Male reached adulthood in a shorter period than that of female. Life cycle decreased from $24.67 \pm 0.26$ to $21.25 \pm 0.53$ days for male and from $28.01 \pm 0.66$ to $23.16 \pm 0.98$ days for female at 25 and $30^{\circ} \mathrm{C}$, respectively. Rate of total survival $=0.73$.

\section{Effect of Temperature on adult female longevity and fecundity: \\ Temperature negatively affected the longevity} and fecundity of $S$. laevigatus when fed on a mixture of the free-living nematode, E. phlagellicaudatus and potato. Adult female longevity decreased when temperature increased from 25 to $30^{\circ} \mathrm{C}$. It lived for $129.81 \pm 5.69$ and $120.15 \pm 5.31$ days at 25 and $30^{\circ} \mathrm{C}$, respectively (Table 2). Adult male followed similar trend as that of female longevity bur having shorter periods.

The present study revealci that female deposited their eggs on substrate. The ags are laid in batches of 3 to 8 in several different licians. Female began to deposit eggs 8 to 10 day an: mergence.

Concerning adult fac.... is is

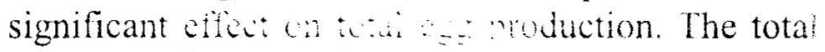
number of egs Acran when temperature 
Table (1): Mean duration (days) of various stages of $S$. laevigatus fed on mixture of the free-living nematode, E. phlagellicaudatus and potato at 25 and $30 \pm 1{ }^{\circ} \mathrm{C}(n=60)$.

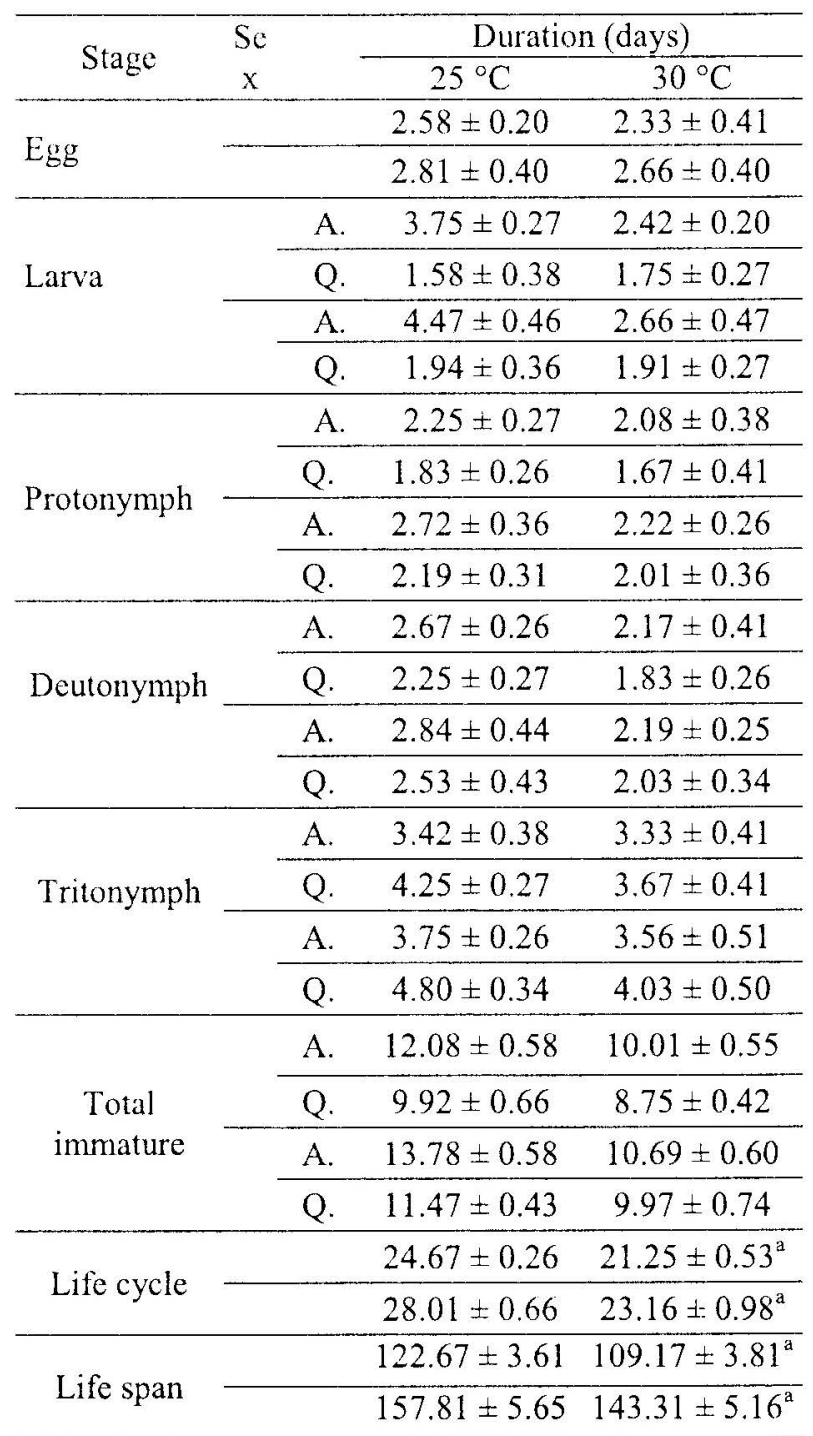

The values are the Mean \pm Standard Deviation $n=$ Starting sample cells

$=$ Female $\mathrm{A} .=$ Active $\mathrm{Q} .=$ Quiescent $\mathrm{a}=$ Significant $\mathrm{P}<0.05$

Table (2): Effect of temperature on adult female longevity and fecundity of $S$. laevigatus fed on a mixture of free-living nematod, E. phlagellicaudatus and potato.

\begin{tabular}{lcc}
\hline Parameters & $25^{\circ} \mathrm{C}$ & $30{ }^{\circ} \mathrm{C}$ \\
\hline Pre-oviposition period & $9.94 \pm 1.12$ & $8.13 \pm 0.81^{\mathrm{a}}$ \\
\hline Generation period & $37.94 \pm 1.28$ & $32.28 \pm 1.35^{\mathrm{a}}$ \\
\hline Longevity & $129.81 \pm 5.69$ & $120.15 \pm 5.31^{\mathrm{a}}$ \\
\hline Mean No.of cggs/female & $36.88 \pm 2.13$ & $29.63 \pm 2.55^{\mathrm{a}}$ \\
\hline $\begin{array}{l}\text { The values are the Mean } \pm \text { Standard Deviation } \\
\mathrm{a}=\text { Significant } \mathrm{P}<0.05\end{array}$
\end{tabular}

increased. It was found that the greatest number of eggs deposited by female was $36.88 \pm 2.13$ occurred at $25^{\circ} \mathrm{C}$. An average female deposited a total eggs $29.63 \pm 2.55$ at $30^{\circ} \mathrm{C}$ (Table 2).

The spermatophore consists of a slender pedicle bearing at its tip a spherical capsule containing sperms. This is in agreement with Woodering and Cook (1962).

The obtained results revealed that increasing of temperature degrees from 25 to $30^{\circ} \mathrm{C}$ decreased the life cycle and adult longevity of $S$. laevigates. The reverse is true with female fecundity. These findings agree with those of Hodkinson et al. (1996) who applied both laboratory and field manipulations, including treatments with temperatures of $30^{\circ} \mathrm{C}$ and above. They found that negative effect on oribatids could be experienced only above $35^{\circ} \mathrm{C}$ and time interval was an important factor in treatments around $30^{\circ} \mathrm{C}$. The extent of tolerance also depended on the moisture of the soil, but it was found that warming had no strong deteriorating effect on oribatids.

\section{REFERENCES}

Behan-Pelletier, V. M. (1999). Oribatid mite biodiversity in agroecosystems: role for bioindication. Agriculture, Ecosystems and Environment, 74: 411 - 423

Darwish, M. A. M. (1977). Biological studies on soil acari. M. Sc. Thesis, Fac. Agric. Cairo Univ., 93 pp.

Erdmann G.; Otte V., Langle R., Scheu S. and Maraun, M. (2007). The trophic structure of bark-living oribatid mite communities analysed with stable isotopes $(15 \mathrm{~N}, 13 \mathrm{C})$ indicates strong niche differentiation. Exp. Appl. Acarol., 41:1- 10.

Hodkinson, I. D.; Coulson, S. J.; Webb, N. R. and Block, W. (1996): Can high Arctic soil microarthropods survive elevated summer temperatures. Functional Ecology 10(3):314- 321 .

of the oribatid mite Scheloribates laevigatus (Acari: Oribatida) in laboratory experiments. Pedobiologia, 43, $328-339$.

Johnston, J. M. and Crossley, D. A. (1993). The significance of coarse woody debris for the diversity of soil mites. In: McMinn, J.W., Crossley, DA. (Eds), Proceedings of the Workshop on Coarse Woody Debris in Southern Forests: Effects on Biodiversity. General Technical Report No. SE-94. LSDA Forest Service, Athens, GA, pp. 82 - 87 .

Kaneko, N. (1988). Feeding habits and cheliceral 
size of oribatid mites in cool temperate forest soils in Japan. Rev. Écol. Biol. Sol, 25: $353-363$.

Khalil, M. A. (2005). Seasonal dynamics of litter decomposition in relation to soil fauna. Egypt. J. Zool., 44: 183 - 198.

Khalil, M. A.; Abd-Ellateif, H. M. and Al-assiuty, A. I. (1999). Changes in oribatid faunal structure associated with land conversion from annual crop into orchard. Pedobiologia, 43: 85 - 96.

Khalil, M. A.; Al-assiuty, A. I. and Van straalen, N. M. (2011). Egg number varies with population density; A study of three oribatid mite species in orchard habitats in Egypt. Acarologia 51(2): $251-258$.

Luxton, M. (1972). Studies on the oribatid mites of a Danish beech wood soil. I.; Nutritional biology. Pedobiologia 12: 434 - 463.

Moore, J. C.; Walter, D. E. and Hunt, H. W. (1988). Arthropod regulation of micro- and mesobiota in below-ground detrital food webs. Ann. Rev. Entomol., 33: 419 - 439.

Narsapur. V. S. (1983). Studies on the biology of Scheloribates laevigatus (Acari : Oribatida) in India. Indian Journal of Acarology, 8 (1): 44 - 48.

Norton, R. A. (1985). Aspects of the biology and systematics of soil arachnids, particularly saprophagous and mycophagous mites. Quaestiones Entomologicae 21: 523 - 541.

Schneider, K. and Maraun, M. (2005). Feeding preferences among dark pigmented fungal taxa ("Dematiacea") indicate limited trophic niche differentiation of oribatid mites (Oribatida, Acari). Pedobiologia 49: 61- 67.

Schneider, K.; Migge, S.; Norton, R. A.; Scheu, S.; Langel, R.; Reineking A. and Maraun, M. (2004). Trophic niche differentiation in soil microarthropods (Oribatida, Acari): evidence from stable isotope ratios $(15 \mathrm{~N} / 14 \mathrm{~N})$. Soil Biology and Biochemistry 36: $1769-1774$.

Seastedt, T. R. (1984). The role of microarthropods in decomposition and mineralization processes. Ann. Rev. Entomol. 29: 25 - 46.

Siepel, H. (1990). Niche relationships between two panphytophagous soil mites, Nothrus silvestris Nicolet (Acari, Oribatida, Northridae) and Platynothrus peltifer (Koch) (Acari, Oribatida, Gamisiidae). Biol. Fertil. Soils, 9: 139 - 144.

Siepel, H. and Maaskamp, F. (1994). Mites of different feeding guilds affect decomposition of organic matter. Soil Biology and Biochemistry 26: 1389 - 1394.

Siepel, H. and Ruiter-Dijkman, E. M. (1993). Feeding guilds of oribatid mites based on their carbohydrase activities. Soil Biology and Biochemistry 26, $1491-1497$.

SPSS Inc., Chicago, IL.

Walter, D. E. and Proctor, H. C. (1999). Mites: ecology, evolution, and behaviour. University of New South Wales Press Ltd, Sydney, Australia, $313 \mathrm{pp}$.

Wolf M. M. and Rockett, C. L. (1984). Habitat changes affecting bacterial composition in the alimentary canal of oribatid mites (Acari: Oribatida). Internat. J. of Acarology 10: 209 215.

Woodering, J. P. and Cook, E. F. (1962). The biology of Ceratozetes cisalpinus Berlese, Scheloribates laevigatus Koch, and Oppia neerlandica Oudemans (Oribatida), with a description of all stages. Acarologia 4: $101-137$.

Zinkler, D.; Götze, M. and Fabian, K. (1986). Cellulose digest

(Apterygota) and oribatid mites. Zoologische Beiträge N.F. 30, 17 - 28. 